\title{
Genotoxic and cytotoxic activities of hexane extract in seeds from Platonia insignis
}

\section{Mart.}

\section{Atividades genotóxicas e citotóxicas do extrato hexânico de sementes de Platonia insignis Mart.}

Actividades genotóxicas y citotóxicas del extracto de hexano in semillas de Platonia insignis Mart.

Maria das Dores Alves de Oliveira ORCID: https://orcid.org/0000-0002-2847-6567 Federal University of Piauí, Brazil E-mail: maralves013@gmail.com

Patrícia e Silva Alves

ORCID: https://orcid.org/0000-0003-0839-9936 Federal University of Piauí, Brazil E-mail: patriciaesilvalves@gmail.com Herbert Gonzaga Sousa

ORCID: https://orcid.org/0000-0001-8633-9918 Federal University of Piauí, Brazil E-mail: herbertgonzaga19@gmail.com Danielle da Costa Silva

ORCID: https://orcid.org/0000-0003-2706-9588 Federal Institute of Piauí, Brazil E-mail: dcsdanielle@gmail.com

Mahendra Kumar Rai

ORCID: https://orcid.org/0000-0001-7645-9801 University Sant. Gadge Baba Amravati, India E-mail: indobraz77@gmail.com Nerilson Marques Lima

ORCID: https://orcid.org/0000-0001-9669-0306 Federal University of Juiz de Fora E-mail: nerilsonmarques@gmail.com

Teresinha de Jesus Aguiar dos Santos Andrade ORCID: https://orcid.org/0000-0002-2415-9222 Federal Institute of Maranhão, Brazil E-mail: teresinha.andrade@ifma.edu.br

Chistiane Mendes Feitosa ORCID: https://orcid.org/0000-0001-8013-1761 Federal University of Piauí, Brazil E-mail: chistiane@ufpi.edu.br

Joaquim Soares da Costa Júnior ORCID: https://orcid.org/0000-0002-9849-201X

Federal Institute of Piauí, Brazil E-mail: jquimjr@ifpi.edu.br

\begin{abstract}
Platonia insignis Mart. is a vegetable of the Clusiaceae Lindl., family that is popularly known as "bacuri" in Brazil. It is widely used in folk medicine to treat human diarrheas and inflammatory diseases. It has antiparasitic activity, antioxidant, anticarcinogenic action, in addition to vasorelaxant potential. The present study investigates the leishmanicidal, cytotoxic and genotoxic activities in different biological systems, as well as the chemical constituents of hexane extract from $P$. insignis seeds. The analysis of the non-volatile constituents was analyzed by GC/MS. A total of sixteen main constituents were detected in the saponifiable material (fatty acid methyl esters, ethyl ester, alcohols and hydrocarbons). In unsaponifiable fraction, nineteen constituents were detected, including a series of $\mathrm{n}$ alkanes and prenylated xanthones gamma-mangostin as main component (70.23\% of the total components). The results indicated that the seed hexane extract significantly inhibits the growth of promastigote forms of Leishmania amazonensis $\left(\mathrm{IC}_{50}\right)$, displayed a significant toxicity against Artemia salina Leach and cytotoxicity and genotoxicity in V79 cell lines.
\end{abstract}

Keywords: Bacuri; Leishmanicidal; Cytotoxicity; Genotoxicity. 


\begin{abstract}
Resumo
Platonia insignis Mart. é um vegetal da família Clusiaceae Lindl., popularmente conhecida como "bacuri” no Brasil. É amplamente utilizado na medicina popular para tratar diarreias humanas e doenças inflamatórias. Possui atividade antiparasitária, ação antioxidante, anticarcinogênica, além de potencial vasorrelaxante. O presente estudo investiga as atividades leishmanicida, citotóxica e genotóxica em diferentes sistemas biológicos, bem como os constituintes químicos do extrato hexânico de sementes de $P$. insignis. A análise dos constituintes não voláteis foi analisada por CG/EM. Um total de dezesseis constituintes principais foram detectados no material saponificável (ésteres metílicos de ácidos graxos, éster etílico, álcoois e hidrocarbonetos). Na fração insaponificável, dezenove constituintes foram detectados, incluindo uma série de n-alcanos e xantonas preniladas gama-mangostina como componente principal (70,23\% dos componentes totais). Os resultados indicaram que o extrato de hexano da semente inibe significativamente o crescimento das formas promastigotas de Leishmania amazonensis ( $\left.\mathrm{CI}_{50}\right)$, apresentou toxicidade significativa contra Artemia salina Leach e citotoxicidade e genotoxicidade em linhagens celulares V79.
\end{abstract}

Palavras-chave: Bacuri; Leishmanicida; Citotoxicidade; Genotoxicidade.

\title{
Resumen
}

Platonia insignis Mart. es un vegetal miembro de la familia Clusiaceae Lindl., que se conoce popularmente como "bacuri" en Brasil. Se usa ampliamente en la medicina popular para tratar las diarreas humanas y las enfermedades inflamatorias. Tiene actividad antiparasitaria, antioxidante, acción anticancerígena, además de potencial vasorrelajante. El presente estudio investiga las actividades leishmanicidas, citotóxicas y genotóxicas en diferentes sistemas biológicos, así como los componentes químicos del extracto de hexano de semillas de P. insignis. El análisis de los constituyentes no volátiles fue analizado por GC/MS. Se detectaron un total de dieciséis componentes principales en el material saponificable (ésteres metílicos de ácidos grasos, ésteres etílicos, alcoholes e hidrocarburos). En la fracción insaponificable se detectaron diecinueve constituyentes, entre ellos una serie de nalcanos y xantonas preniladas gamma-mangostina como componente principal (70,23\% del total de componentes). Los resultados indicaron que el extracto de semilla de hexano inhibe significativamente el crecimiento de formas promastigotas de Leishmania amazonensis $\left(\mathrm{IC}_{50}\right.$ ), mostró una toxicidad significativa contra Artemia salina Leach y citotoxicidad y genotoxicidad en líneas celulares V79.

Palabras clave: Bacuri; Leishmanicida; Citotoxicidad; Genotoxicidad.

\section{Introduction}

Medicinal plants play a prominent role in the health system around the world, this involves the use of medicinal plants not only for the treatment of diseases, but also as a potential material for the maintenance of good health conditions. used in medicines to maintain physical, mental and social health (Devi et al., 2021; Garg et al., 2021). However, despite the therapeutic advantages of medicinal plants, some of their chemical constituents can be potentially toxic, mutagenic, carcinogenic or teratogenic (Doroftei et al., 2019). Studies have shown that many plants have considered toxicity (Campos et al., 2016; Matos et al., 2011). Therefore, it is important to screen medicinal plants for their cytogenotoxic potential, since genotoxicity is one of the main causes of the onset and development of many types of cancer (Schultz et al., 2021).

The Clusiaceae Lindl. family includes 2 genera divided into almost one thousand of species that are distributed throughout tropical regions of the world (The Plant List, 2022). The most commonly cited genera include Clusia, Rheedia, Garcinia, Hypericum, Allanblackia, Kielmeyera, Symphonia, Calophyllum, Mammea and Pentadesma (Souza et al., 2000). Extensive phytochemical studies have shown Clusiaceae to be a rich source of secondary metabolites including xanthones, triterpenoids, flavonoids, lactones, organic acids (Piccimelli et al., 2005) and polyprenylated benzophenones (Silva et al., 2016). These metabolites have been shown to possess antiviral, antioxidant, anti-inflammatory, antifungal, antimicrobial, anticonvulsant (Silva et al., 2014), anxiolytic, cytotoxic (Prado et al., 2017) and wound healing activities (Weng et al., 2004; Piccinelli et al., 2005; Ciochina \& Grossman, 2006; Hosni et al., 2010; Zhang et al., 2010).

Platonia insignis Mart., (Clusiaceae) commonly known as "bacuri", is a native species of the Brazilian Amazonia region composed of pulp, shell and seeds (Monteiro et al., 1997). The fruits of P. insignis can be consumed raw or as juice, ice cream or jam. While the seeds from $P$. insignis is used to treat various skin diseases in both humans and animals, the seed decoction is used to treat human diarrhea and inflammatory diseases (Agra et al., 2007). The ethanolic extract demonstrated a strong protective effect on the central nervous system and garcinielliptone, isolated from the hexane extract seeds, an 
antioxidant action (Costa Júnior et al., 2010; Costa Júnior et al., 2011a).

The constituents of the shell from P. insignis are well known. They predominantly include free fatty acids (palmitic, oleic, linoleic, $\alpha$-linolenic, stearic, caprylic and myristic acids), alcohols (e.g., linalool, $\alpha$-terpineol and 3,7-dimethyl-oct-1-en3,7-diol), oxides (e.g., cis-linalool oxide and trans-linalool oxide), trimethyl citrate and the phenolether eugenol (Monteiro et al., 1997). In contrast, the composition of $P$. insignis seed remains rather unknown; to date, a few acids (Bentes et al., 1986) and a compound garcinielliptone (Costa Júnior et al., 2011a; Bezerra et al., 2020) were described. The latter compound with important antiparasitic activity (Silva et al., 2015), antioxidant and anticarcinogenic activities (Costa Júnior et al., 2012), besides vasorelaxant effect (Arcanjo et al., 2014).

The xanthones are the major secondary metabolites found in the seeds of the bacuri fruits (Costa Júnior et al., 2011b). A broad range of biological activities of xanthones have been reported extensively, especially cytotoxicity on a variety of cancer cells, e.g. human breast cancer, colorectal cancer, hepatoma, leukaemia, and small cell lung cancer (Pedraza-Chaverri et al., 2008; Wang et al., 2011). These cytotoxicities were found to be associated with anti-proliferative and apoptotic effects.

There are no studies reporting the cytotoxicity of $P$. insignis seed extract. In view of the popular use and the absence of knowledge about the cytotoxic potential of $P$. insignis, the aim of this work was to identify the chemical constituents of $P$. insignis seeds hexane extract by GC/MS, and its toxic effects by employing three biological models: Leishmania amazonensis, Artemia salina Leach, and permanent mammalian fibroblast cell line derived from Chinese hamsters (V79 cells). The toxicity was determined in L. amazonensis (leishmanicidal activity) and A. salina. The V79 cells were employed to measure the cytotoxic effects by MTT assay and genotoxicity by using the standard comet assay.

\section{Methodology}

\subsection{Chemicals}

DMEM (Dulbecco’s modified Eagle medium), FBS (fetal bovine serum), trypsin-EDTA were obtained from GIBCO ${ }^{\circledR}$ (Grand Island, NY, USA). MMS (methyl methanesulphonate), MTT (3-(4,5-dimethylthiazole-2-yl)-2,5-biphenyl tetrazolium bromide) was purchased from Sigma (St. Louis, MO, USA). Low melting point agarose and agarose were obtained from Invitrogen (Carlsbad, CA, USA). All other reagents were of analytical grade.

\subsection{Sample extraction}

The fruits of P. insignis were collected from Barras, Piauí State, Brazil in March 2009. A voucher specimen was identified and deposited at the Herbarium of the Biology Department of the Federal University of Piauí, Brazil (Voucher No. ICN TEPB27164). The seeds were dried at $55^{\circ} \mathrm{C}$ and powdered in a Soxhlet apparatus, the powder $(848.2 \mathrm{~g})$ was extracted with hexane $(63 \%$, w/w). The hexane extract (hexane. Ext.) was subjected to saponification followed by methylation reaction (Hartman \& Lago, 1973) and a small portion (F. saponifiable and F.unsaponifiable) of the crude reaction was analyzed in GC/MS (Gas Chromatography coupled to the detector by Mass Spectrometry).

\subsection{Gas chromatography/mass spectrometry (GC/MS) analysis}

The saponifiable and unsaponifiable fractions from $P$. insignis seeds were analyzed by gas chromatography to determine the fatty acid composition. The fractions 10 $\mu 1$ were analyzed using a Shimadzu GC-17A/MS QP5050A (GC/MS system) and a DB-5HT capillary column (30 $\mathrm{m} \times 0.251 \mathrm{~mm}, 0.1 \mu \mathrm{m}$ film thickness). The experimental conditions used were: carrier gas; helium $1.7 \mathrm{~mL} / \mathrm{min}$; column inlet pressure $=107.8 \mathrm{kPa}$; column flow $=1.7 \mathrm{~mL} / \mathrm{min}$; linear velocity $=47.3 \mathrm{~cm} / \mathrm{sec}$; total flow $=24 \mathrm{~mL} / \mathrm{min}$; carrier flow $=24 \mathrm{~mL} / \mathrm{min}$; injector temperature $=280^{\circ} \mathrm{C}$; detector temperature $=300^{\circ} \mathrm{C}$; and column temperature $=80(1 \mathrm{~min})-300^{\circ} \mathrm{C}$ at $10^{\circ} \mathrm{C} / \mathrm{min}(15 \mathrm{~min})$. The ionization energy used for the mass spectrometer was $70 \mathrm{eV}$. The 
mass spectra were recorded from $40-650 \mathrm{~m} / \mathrm{z}$. The quantity of all identified components was investigated by using a percent relative peak area. The tentative identification of the compounds was performed based on the comparison of their relative retention time and mass spectra with those of the WILEY229 library data of the GC/MS system. Spectra were considered coincident if the similarity index was higher than $90 \%$.

\subsection{In vitro leishmanicidal activity}

Promastigote forms of $L$. amazonensis (IFLA/BR/67/PH-8) in the $\log$ phase of growth $\left(1 \times 10^{6}\right.$ parasites $/ \mathrm{mL}$ ) were incubated with seeds-extract of $P$. insignis at $26^{\circ} \mathrm{C}$ in Schneider's medium (Sigma, USA) supplemented with $10 \%$ of FBS. Amphotericin B was used as a control. After $48 \mathrm{~h}$, parasites were collected, fixed in an isotonic solution (10.5 g citric acid, 7.0 $\mathrm{g} \mathrm{NaCl}, 5.0 \mathrm{~mL}$ formalin and $1,000 \mathrm{~mL}$ distilled water) and examined using light microscopy. The inhibitory effect of the fraction on cellular growth was estimated by cell counting using a Neubauer chamber. The concentration that inhibited 50\% of the growth $\left(\mathrm{IC}_{50}\right)$ was determined by regression linear analysis (Oliveira-Silva et al., 2008).

\subsection{Toxicity against $A$. salina Leach.}

The brine shrimp assay is a safe, practical, and economical method to determine the bioactivity of natural compounds. The brine shrimp lethality bioassay was performed following the reported procedure (Meyer et al., 1982). The growth medium was prepared with filtered seawater in a small tank divided into two compartments. Shrimp eggs were added to the covered compartment, and a lamp was placed above the open side of the tank to attract hatched shrimps through perforations in the partition wall. After $48 \mathrm{~h}$, the shrimps matured as nauplii (A. salina Leach.) and were ready for the assay. Stock solutions of the extracts of $P$. insignis seeds were prepared in dimethylsulfoxide (DMSO) and seawater and filtered (the final concentration of DMSO in the mixture never exceeded $0.2 \% \mathrm{v} / \mathrm{v}$ ). Appropriate volumes of stock solutions were then added to the tubes containing seawater and 10 nauplii each. Four different extract concentrations were applied in triplicate to each tube. After 24 $\mathrm{h}$ of incubation under light, the numbers of dead and surviving brine shrimps were counted in each tube. The $\mathrm{LC}_{50}$ values were calculated from the graphics of drug concentration versus lethality percentage using a probit adjust scale.

\subsection{V79 cell culture and treatment}

Chinese hamster lung fibroblast cells (V79 cells) were cultured under standard conditions in DMEM supplemented with $10 \%$ heat-inactivated-FBS, $0.2 \mathrm{mg} / \mathrm{mL}$ L-glutamine, $100 \mathrm{IU} / \mathrm{mL}$ penicillin and $100 \mathrm{~g} / \mathrm{mL}$ streptomycin. Cells were kept in tissue-culture flasks at $37^{\circ} \mathrm{C}$ in a humidified atmosphere containing $5 \% \mathrm{CO}_{2}$ in air and were harvested by treatment with $0.15 \%$ trypsin-0.08\% EDTA in PBS. Cells $\left(5 \times 10^{5}\right.$ cells) were seeded in the medium and grown for one day prior to treatment with hexane extract. The hexane extract of $P$. insignis seeds was dissolved in DMSO and added to the FBS-free medium to give various concentrations $(10,25,50$ and $100 \mu \mathrm{g} / \mathrm{mL})$. The cells were treated for $2 \mathrm{~h}$ under standard conditions. The appropriate concentrations were obtained by dilution of stock solution in sterile distilled water and the final concentration of DMSO in the incubation mixture never exceeded $0.2 \%(\mathrm{v} / \mathrm{v})$.

\subsubsection{MTT assay}

The MTT assay was performed according to Denizot \&Lang (1986). After treatments, cells were briefly washed with PBS. A serum-free medium $(0.15 \mathrm{~mL}$ ) containing a yellow dye of a tetrazolium salt (MTT; $1 \mathrm{mg} / \mathrm{mL}$ ) was then added and the mixture was incubated for $3 \mathrm{~h}$ at $37^{\circ} \mathrm{C}$. After incubation, the supernatant was removed. The residual purple formazan product was solubilized in $0.2 \mathrm{~mL}$ DMSO and stirred for $15 \mathrm{~min}$. The absorbance of the product was measured at $570 \mathrm{~nm}$. The absorbance of the negative control (solvent) was considered as corresponding to the viability of $100 \%$, and the values of 
treated cells were calculated as a percentage of the negative control (solvent).

\subsubsection{Comet assay V79 cell culture}

An alkaline comet assay was performed as described by Hartmann \& Speit (1997) and Tice et al. (2000) with minor changes. At the end of the treatment, the cells were washed with ice-cold PBS and trypsinized with $100 \mu \mathrm{L}$ of trypsin $(0.15 \%)$. Immediately thereafter, $20 \mu \mathrm{L}$ of the cell suspension was dissolved in $0.75 \%$ low-melting-point agarose (Hartmann et al., $2001)$ and spread on regular pre-coated agarose-point (1\%) microscope slides. Cells were ice-cold lysed (2.5 M NaCl, $100 \mathrm{mM}$ EDTA, and $10 \mathrm{mM}$ Tris, $\mathrm{pH} 10.0$, with freshly added $1 \%$ Triton X-100 and 10\% DMSO) at $4{ }^{\circ} \mathrm{C}$ for at least $1 \mathrm{~h}$ in order to remove cellular proteins and membranes, with DNA remaining as "nucleoids." The slides were then placed in a horizontal electrophoresis box containing a freshly prepared alkaline buffer $(300 \mathrm{mM} \mathrm{NaOH}$ and $1 \mathrm{mM}$ EDTA, pH $\sim 13.0)$ at $4{ }^{\circ} \mathrm{C}$ for 20 min to allow DNA unwinding. A $300 \mathrm{~mA}$ and $25 \mathrm{~V}(0.90 \mathrm{~V} / \mathrm{cm})$ electric current were applied for 20 min to perform DNA electrophoresis. All of the above steps were performed under yellow light or in the dark to prevent additional DNA damage. The slides were then neutralized (0.4 M Tris, pH 7.5), stained with silver nitrate as described by Nadin et al. (2001), and analyzed using an optical microscope. One hundred cells (50 cells from each of two replicate slides of each organ or tissue) were selected and analyzed for DNA migration. When selecting cells, edges and cells around air bubbles were discarded (Tice et al., 2000). Cells were visually scored according to tail length into five classes: (1) class 0: undamaged with no tail; (2) class 1: tail shorter than the diameter of the head (nucleus); (3) class 2: tail as long as 1-2x the diameter of the head; (4) class 3: tail longer than $2 \mathrm{x}$ the diameter of the head; and (5) class 4: comets with no heads. Visual scoring of comets is considered a valid evaluation method in international guidelines and recommendations for the comet assay (Burlinson et al., 2007; Hartmann \& Speit, 1997; Tice et al., 2000). The damage index (DI) is an arbitrary score calculated for cells in different damage classes that were visually scored by measuring the DNA migration length and the amount of DNA in the tail. DI was thus assigned to each comet according to its class and ranged from 0 (Completely undamaged: 100 cells $\times 0$ ) to 400 (With maximum damage: 100 cells $\times 4$ ). Damage frequency (DF), which is the proportion of cells presenting tails after electrophoresis, was also considered in our study. The DF (\%) was calculated as the number of cells with tails versus those without (0-100\%) (Hartmann \& Speit, 1997).

\subsection{Statistical analysis}

All experiments were independently repeated at least three times, with triplicate samples for each treatment. The experimental results were expressed as mean and standard deviation (S.D.). Data were analyzed by one-way analysis of variance (ANOVA) and the means were compared using the Tukey test. A $P$ value lower than 0.05 was considered to be statistically significant. Data analysis was performed with SPSS 10.0 for Windows and GraphPad Prism version 4.00, GraphPad Software (San Diego, USA).

\section{Results}

\subsection{Identification of the main compounds in hexane extract from seeds of $P$. insignis}

The analysis of the non-volatile constituents (hexane extract, yields ranged from $63 \%$, w/w) from P. insignis seeds was analyzed by GC/MS. As showed in Table 1 a total of fifteen main constituents were detected in the F. saponifiable and $97.48 \%$ out of this total was identified as fatty acid methyl esters, ethyl ester, alcohols, and hydrocarbons. The saturated palmitic acid $(25.31 \%)$ and unsaturated oleic acid (27.59\%) are the major compounds in F. saponificable P. insignis seeds hexane extract. The F. unsaponifiable of fourteen constituents were detected by GC/MS representing $89.98 \%$. In this fraction 
the major compound was 1,3,6,7-tetrahydroxy-2,8-bis(3-methylbut-2-enyl)xanthen-9-one, gamma-mangostin, representing $70.23 \%$ of the total components (Table 1$)$.

Table 1. Main Compounds detected in the F. saponifiable and F. unsaponifiable from hexane extract from seeds of $P$. insignis.

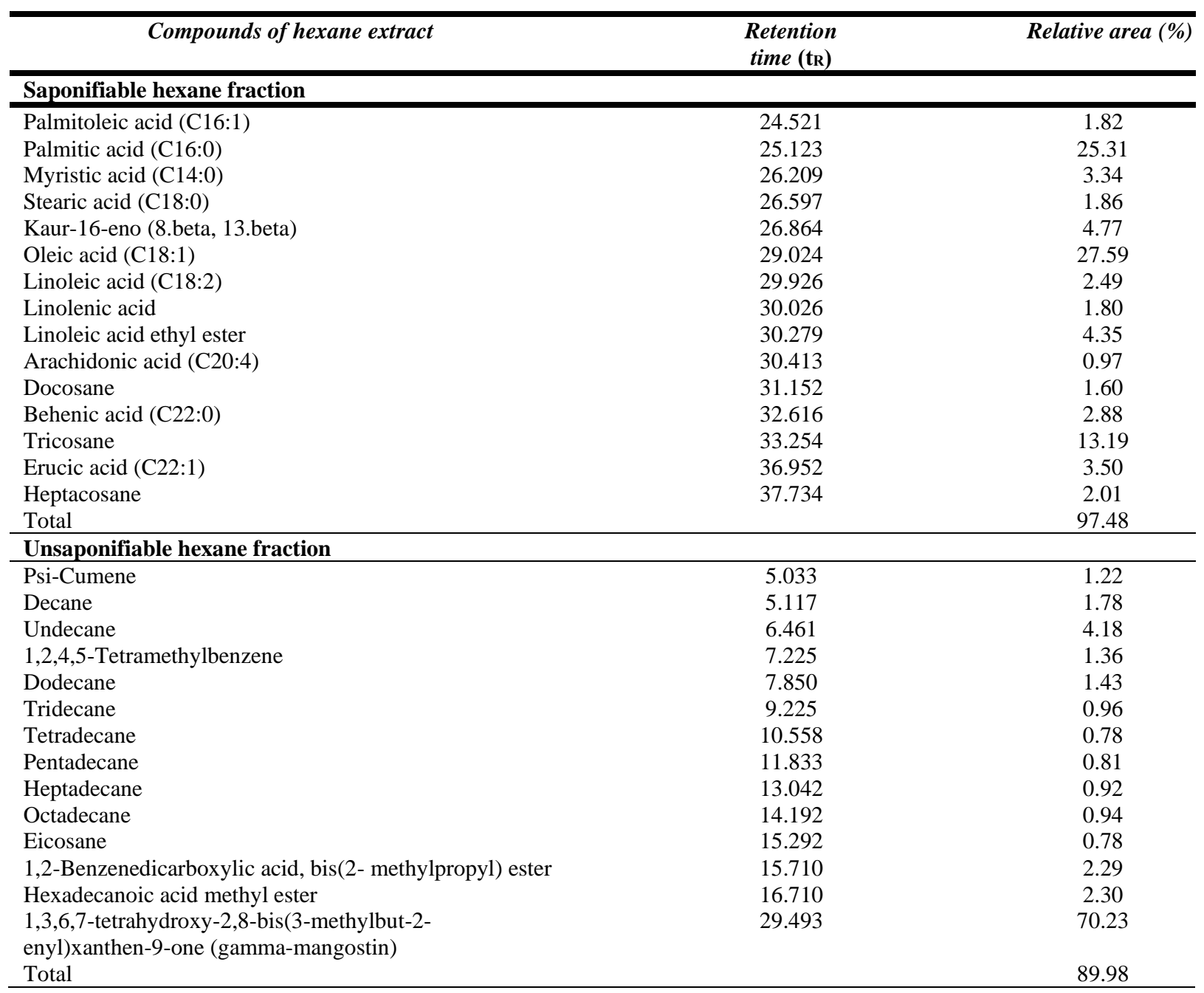

Source: Authores.

\subsection{In vitro leishmanicidal activity}

The $P$. insignis seeds hexane extract strongly inhibited the growth of the promastigote form of L. amazonensis. After $48 \mathrm{~h}$ of incubation, the $\mathrm{IC}_{50}$ value for the hexane was $3.49 \mu \mathrm{g} / \mathrm{mL}$. The $\mathrm{IC}_{50}$ value for amphotericin $\mathrm{B}$ was $0.04 \mu \mathrm{g} / \mathrm{mL}(\mathrm{Table}$ 2).

Table 2. Promastigote anti-leishmania activity and toxicity against A. salina of hexane extract from P. insignis seeds.

\begin{tabular}{|c|c|c|}
\hline Extracts & $\begin{array}{l}I C_{50}(\mu g / m L)^{a, b} \\
\text { L. amazonenses }\end{array}$ & $\begin{array}{l}I C_{50}(\mu g / m L)^{a} \\
\text { A. salina }\end{array}$ \\
\hline & $48 \mathrm{~h}$ & $24 \mathrm{~h}$ \\
\hline Hexane extract & 3.49 & 130.9 \\
\hline
\end{tabular}

${ }^{\mathrm{a}}$ The $\mathrm{IC}_{50}$ values obtained from a minimum of three separate experiments performed in triplicate are shown $(95 \%$ confidence limits). ${ }^{b}$ Positive control: amphotericin B (IC $500.04 \mu \mathrm{g} / \mathrm{mL}$ ). Source: Authors. 


\subsection{Toxicity against Artemia salina Leach.}

According to McLaughlin (1991), compounds with IC50 $<1.000 \mathrm{ppm}$ in the brine shrimp lethality assay are considered active and potentially cytotoxic against cell lines. The hexane. Ext. presented $\mathrm{IC}_{50}$ of $130.9 \mu \mathrm{g} / \mathrm{mL}$ and considered toxicity against brine shrimps (Table 2). The control samples with solvents (seawater and DMSO) did not lead to significant brine shrimp mortality.

\subsection{V79 cells cytotoxicity measured by an MTT assay}

The MTT assay was used for evaluation of the cytotoxicity of the P. insignis seeds hexane extract in V79 cells and was shown in Figure 1. At low tested concentrations, the hexane extract did not induce significant cytotoxic effects. At concentrations up to $100 \mu \mathrm{g} / \mathrm{mL}$ the hexane extract was cytotoxic with a significant decrease in survival.

Figure 1. Survival of V79 cells after exposure to hexane extract of $P$. insignis seeds after $2 \mathrm{~h}$ by MTT assay.

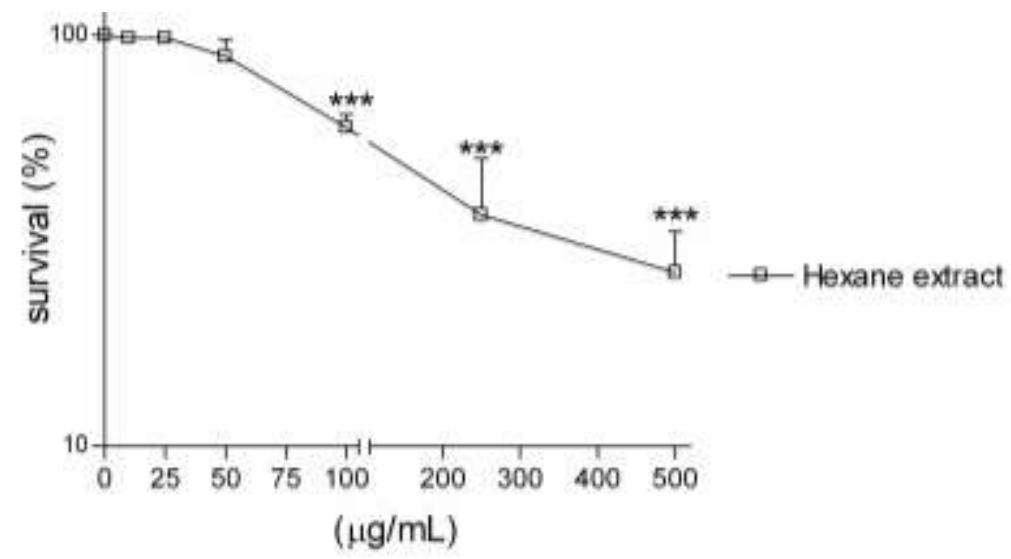

Values shown are the mean and standard deviation at least three determinations. $* * *$ Significant difference as compared to the negative control (solvent; DMSO 0.2\%) at $P<0.001 /$ One-way ANOVA Tukey's multiple comparison test. Source: Authors.

\subsection{V79 cell genotoxicity by comet assay}

The induction of genotoxicity by $P$. insignis in V79 cell lines using an alkaline version of the comet assay is shown in Table 3. The hexane extract clearly resulted in a significant increase in DI and DF values, as compared to the values obtained for the control groups, at concentrations of up to $25 \mu \mathrm{g} / \mathrm{mL}$. In addition, this increase in damage score occurred in a doserelated manner.

Table 3. Induction of DNA strand breaks from hexane extract of P. insignis seeds in V79 cells as evaluated by the comet assay.

\begin{tabular}{lccc}
\hline Agent & Treatment $(\mu g / m L)$ & \multicolumn{1}{c}{$D I^{c}$} & $D F(\%)^{d}$ \\
\hline Alkaline conditions $(\mathrm{pH} \sim 13.0)$ & & \\
$\mathrm{NC}^{\mathrm{a}}$ & & $14.33 \pm 4.41$ & $14.00 \pm 4.64^{\mathrm{e}}$ \\
$\mathrm{MMS}^{\mathrm{b}}$ & 40 & $120.30 \pm 13.66^{* * * *}$ & $76.00 \pm 6.75^{* * *}$ \\
& & & \\
Hexanic extract & 10 & $43.00 \pm 9.85^{* * *}$ & $14.50 \pm 1.64$ \\
& 25 & $69.00 \pm 1.09^{* * *}$ & $29.00 \pm 2.19^{* *}$ \\
& 50 & $91.00 \pm 4.38^{* * * *}$ & $31.00 \pm 3.28^{* * * *}$ \\
& 100 & $132.0 \pm 4.38^{* * *}$ & $54.50 \pm 1.64^{* * *}$ \\
\hline
\end{tabular}

${ }^{\mathrm{a}}$ Negative control (solvent; DMSO 0.2\%). ${ }^{\mathrm{b}}$ Positive control. ${ }^{\mathrm{c}} \mathrm{DI}$, damage index. ${ }^{\mathrm{d}} \mathrm{DF}$, damage frequency. ${ }^{\mathrm{e}}$ Mean value and standard deviation obtained from an average of 100 cells per experiment - total of three independent experiments per concentration of hexane extract. * Significant difference as compared to the negative control (solvent; DMSO 0.2\%) at $\mathrm{P}<0.05 ; * * \mathrm{P}<0.01$; $* * * \mathrm{P}<0.001 /$ One-way ANOVA Tukey's multiple comparison test. Source: Authors. 


\section{Discussion}

The saponifiable portion of $P$. insignis seeds (bacuri fat) is yellowish, solid and rich in triacylglycerols and fatty acids. Hilditch and Pathak (1949) determined the composition of bacuri fat; they found that its main acidic components were palmitic $(55 \%)$ and oleic (32\%) acids, with smaller proportions of stearic (6\%) and palmitoleic (3\%) acids and traces of myristic, arachidic, and linoleic acids. Our results, shown in Table 1, differ from previously reported data (Bentes et al., 1986; Hilditch \& Pathak, 1949). In our study, palmitic (25.31\%) and oleic (27.59\%) acids also contributed significantly to the composition of the oil, although both studies revealed palmitic and oleic acid as the main constituents.

As shown in Table 1, oleic and palmitic acids are the most abundant fatty acids present in hexane extract. In addition, ester and hydrocarbon residues are freed from unsaponifiable matter. Despite a total molar content of $35 \%$ of unsaturated acids, the fat contained over $20 \%$ of trisaturated glycerides (largely tripalmitin), which is different from the majority of seed fats.

The antimicrobial, trypanocidal and antitumoral activities of natural products are mainly associated with prenylated compounds, especially in the case of benzophenones. It has been suggested that the biological activity of a compound can be increased by increasing the number of attached prenyl residues (Pereira et al., 2010). In addition, benzophenones isolated from plants were found to display a high antioxidant activity and protect cells from oxidative stress and the formation of reactive oxygen species (ROS) that are involved in inflammatory processes (Acuna et al., 2009).

Leishmaniasis is a public health problem in developing countries, where 350 millions people are at risk of infection. Systematic studies in different parts of the world searching for the anti-protozoal activity of medicinal plants have been reported (Braga et al., 2007). In the present study, P. insignis seeds showed a potent inhibitory effect against the promastigote form (Table 2). The results described in this study provide an additional contribution to the development of new compounds with potential anti-leishmanial properties. Nevertheless, further studies are required to characterize the active component of $P$. insignis against Leishmania, using highly purified compounds. A systematic in vitro evaluation of an extract obtained from the latex of Moronobea coccinea Aubl. (Clusiaceae) exhibited a strong anti-plasmodial activity against Plasmodium falciparum that was attributed to the presence of polycyclic polyprenylated acylphloroglucinols (Marti et al., 2009).

The use of plants in therapies is a worldwide phenomenon. Currently, drugs derived from plants are being investigated for the possible presence of cytotoxic, mutagenic and genotoxic substances, as well as other biological activities. The detection and evaluation of the cytotoxic, mutagenic and carcinogenic effects of plant compounds are of fundamental importance to minimize the possible risks of these agents. Many plants occasionally consumed by the human population can have toxic effects (Varanda et al., 2002).

The MTT assay was used to obtain information on cytotoxicity of $P$. insignis seeds hexane extract in V79 cells. A significant decrease in survival was observed at concentrations of up to $100 \mu \mathrm{g} / \mathrm{mL}$ (Figure 1). This information is important for the evaluation of the safety of this compound for possible pharmacological applications and for the study of the mechanisms underlying its anti-proliferative effects.

A literature review from a chemical and biological point of view for the genus Calophyllum (Clusiaceae) reveals a cytotoxic activity against several cell lines due to the presence of coumarins, xanthones, flavonoids, and triterpenes (Cechinel Filho et al., 2009). Among the eight Calophyllum species found on the American continent, Calophyllum brasiliense is the most widely distributed. Chemical analysis of this species revealed the presence of xanthones having chemo-preventive properties and anti-fungal activity. A cytological study showed that coumarins from C. brasiliense reduced the survival of BMK cells (baby mouse kidney cells) by inducing apoptosis and, to a lesser degree, necrosis. Several xanthones, coumarins, terpenoids and phenolic compounds were isolated from $C$. brasiliense with remarkable activities, including anti-HIV, antibacterial, trypanocidal, and anti-cancer against KM-12 (colon adenocarcinome), U-251 (gliome), PC-3 (prostate), and K-562 
and HL-60 (leukemias) cell lines (Mesquita et al., 2009).

The evaluation of genotoxic damage caused by plant compounds together with a cytotoxicity determination is important to minimize the possible risks of these agents, especially when they are part of a long-term treatment (Cardozo et al., 2006).

The alkaline, single-cell gel electrophoresis (comet) assay has become a widely used method for the detection of DNA damage and repair in cells and tissues (Moøller et al., 2010). In this study, we showed that the hexane extract of P. insignis seeds induced genotoxicity in the V79 cell line in a dose-related manner (Table 3). The alkaline comet assay $(\mathrm{pH}>13) \mathrm{can}$ detect single and double-stranded breaks, incomplete repair sites, alkali labile sites, and possibly both DNA-protein and DNADNA cross-links in almost any eukaryotic cell population that can be obtained as a single cell suspension (Burlinson et al., 2007). The genotoxic effects observed in our study with this assay can be explained by the results of the chemical constituents detected in the extracts.

The seeds from $P$. insignis are rich in free fatty acids, as shown in Table 1. Palmitic, oleic, linoleic, $\alpha$-linolenic, and stearic acids were also identified in $P$. insignis seeds. Saturated fatty acids induce DNA damage and cause apoptotic cell death in insulin-producing beta-cells. Palmitate and stearate, but not linoleate, oleate and palmitoylmethyl esters, induced growth inhibition and increased apoptosis in RINm5F cells following a 24-h exposure. However, linoleic acid protected against palmitic-acid-induced apoptotic and necrotic cell death (Beeharry et al., 2004). As also shown in Table 1, the amount of saturated fatty acids in P. insignis and the percentage of oleic and palmitic acids were high relative to those of other compounds. Oleic acid is more steatogenic, but less apoptotic, than palmitic acid in hepatocyte cell cultures (Ricchi et al., 2009). A promising study by Souza et al. (2017) using stem bark extract showed the inhibitory values of the EtOH-Ext, Hex-F, and Lupeol inhibited the growth of $L$. Amazonenses promastigote forms at $\mathrm{IC}_{50}$ of $174.24,45.23$, and $39.06 \mu \mathrm{g} / \mathrm{mL}$, respectively, as well as $L$. amazonenses axenic amastigote forms at $\mathrm{IC}_{50}$ of $40.58,35.87$, and $44.10 \mu \mathrm{g} / \mathrm{mL}$, respectively. The mean cytotoxic concentrations for macrophages $\left(\mathrm{CC}_{50}\right)$ were higher than those for amastigotes $(341.95,71.65$, and $144.0 \mu \mathrm{g} / \mathrm{mL}$, resp.), indicating a selective cytotoxicity towards the parasite rather thanthe macrophages. Interestingly, all treatments promoted antileishmanial effect against macrophage-internalized amastigotes atconcentrations lower than $\mathrm{CC}_{50}$.

The unsaponifiable hexane fraction has gamma-mangostin as a major compound (Table 1). Matsumoto et al. (2005) have demonstrated that the antiproliferative effects of $\alpha$ - and $\gamma$-mangostins are associated with apoptosis in human colon cancer DLD-1 cells. Suksamrarn et al. (2006) demonstrated that mangostenone C, mangostenone D, demethylcalabaxanthone, $\beta$-mangostin, gartanin, garcinone $\mathrm{E}, \alpha$-mangostin, mangostinone, $\gamma$-mangostin, garcinone $\mathrm{D}$, and garcinone $\mathrm{C}$ induce cytotoxic effects on three human cancer cell lines. Laphookhieo et al. (2006) found that $\alpha$ - and $\gamma$-mangostins have a cytotoxic effect against NCI-H187. Six xanthones including $\alpha$-mangostin, garcinone E, gartanin, and $\gamma$-mangostin showed antibacterial activity against MRSA (Iinuma et al., 1996). $\alpha$ and $\gamma$-mangostins and garcinone B exhibited a strong inhibitory effect against Mycobacterium tuberculosis (Suksamrarn et al., 2003). Chen et al. (1996) showed that the ethanolic extract of G. mangostana effectively inhibited HIV-1 protease.

\section{Conclusion}

In conclusion, the present findings indicate that hexane extract of $P$. insignis seeds are toxic against $A$. salina, present leishmanicidal activity on promastigote forms, and are cytotoxic and genotoxic in V79 mammalian cell lines. All these activities seem to be related, at least in part, to the chemical composition that includes the presence of saturated fatty acids and xanthone (gamma-mangostin). Further studies are needed to identify the molecular mechanism underlying hexane extract of $P$. insignis seeds induced-cytotoxicity in different biological models. 


\section{Acknowledgments}

The authors are grateful to Foundation for Research Support of the State of Piauí (FAPEPI), Foundation for Research Support of the State of Rio Grande do Sul (FAPERGS), Federal Institute of Piauí (IFPI), National Council for Scientific and Technological Development $(\mathrm{CNPq})$ and National Institute for Translational Research in Health and Environment in the Amazon (INPeTAm/CNPq/MCT), Brazil.

\section{Conflict of Interest}

The authors declare that there are no conflicts of interest.

\section{References}

Acuña, U. M., Jancovski, N., \& Kennelly, E. J. (2009). Polyisoprenylated Benzophenones from Clusiaceae: Potential Drugs and Lead Compounds. Current Topics in Medicinal Chemistry, 9 (16), 1560-1580. https://doi.org/10.2174/156802609789909830

Agra, M. F., Freitas, P. F., \& Barbosa-Filho, J. M. (2007). Synopsis of the plants known as medicinal and poisonous in Northeast of Brazil. Revista Brasileira de Farmacognosia, 17 (1), 114-140. https://doi.org/10.1590/S0102-695X2007000100021

Arcanjo, D. D. R., Costa-Júnior, J. S., Moura, L. H. P., Ferraz, A. B. F., Rosatto, R. R., David, J. M., Quitans-Júnior, L. J., Oliveira, R. C. M., Citó, A. M. G. L., \& Oliveira, A. P. (2014). Garcinielliptone FC, a polyisoprenylated benzophenone from Platonia insignis Mart., promotes vasorelaxant effect on rat mesenteric artery. Natural Product Research, 28 (12), 923-927. https://doi.org/10.1080/14786419.2014.889136

Beeharry, N., Chambers, J. A., \& Green, I. C. (2004). Fatty acid protection from palmitic acid-induced apoptosis is lost following PI3-kinase inhibition. Apoptosis, 9 (5), 599-607. https://doi.org/10.1023/B:APPT.0000038039.82506.0c

Bentes, M. H. S., Serruya, H., Rocha Filho, G. N., Godoy, R. L. O., Cabral, J. A. S., \& Maia, J. G. S. (1986). Estudo químico das sementes de bacuri. Acta Amazonica, 16, 363-368. https://doi.org/10.1590/1809-43921986161368

Bezerra, E. A., Alves, M. M. M., Amorim, L. V., Carvalho, R. C. V., Cruz, L. P. L., Costa-Júnior, J. S., Oliveira, M. D. A., Lima Neto, J. S., Carvalho, F. A. A., Citó, A. M. G. L., \& Arcanjo, D. D. R. (2020). Garcinielliptone FC: Selective anti-amastigote and immunomodulatory effects on macrophages infected by Leishmania amazonenses. Toxicology in Vitro, 63, 1-7.

Braga, F. G., Bouzada, M. L., Fabri, R. L., Matos, M. O., Moreira, F. O., Scio, E., \& Coimbra, E. S. (2007). Antileishmanial and antifungal activity of plants used in traditional medicine in Brazil. Journal of Ethnopharmacology, 111 (2), 396-402. https://doi.org/10.1016/j.jep.2006.12.006

Burlinson, B. B., Tice, R. R., Speit, G., Agurell, E., Brendler-Schwaab, S. Y., Collins, A. R., Escobar, P., Honma, M., Kumaravel, T. S., Nakajima, M., Sasaki, Y. F., Thybaud, V., Uno, Y., Vasquez, M., \& Hartmann, A. (2007). Fourth International Workgroup on Genotoxicity testing: results of the in vivo Comet assay workgroup. Mutation Research, 627 (1), 31-35. https://doi.org/10.1016/j.mrgentox.2006.08.011

Campos, S.C., Silva, C.G.; Campina, P.R.V. \& Almeida, V. L. (2016). Toxicidade de espécies vegetais. Rev. Bras. Pl. Med., 18 (1), 373-382. https://doi.org/10.1590/1983-084X/15_057

Cardozo, T. R., Rosa, D. P., Feiden, I. R., Rocha, J.A.V., Oliveira, N. C. D., Pereira, T. S., Pastoriza, T. F., Marques, D. M., Lemos, C. T., Terra, N. R., \& Vargas, V. M. F. (2006). Genotoxicity and toxicity assessment in urban hydrographic basins. Mutation Research, 603 (1), 83-96. https://doi.org/10.1016/j.mrgentox.2005

Cechinel Filho, V., Meyre-Silva, C., \& Niero, R. (2009). Chemical and pharmacological aspects of the genus Calophyllum. Chemistry \& Biodiversity, 6 (3), 313-327.

Chen, S. X., Wan, M., \& Loh, B. N. (1996). Active constituents against HIV-1 protease from Garcinia mangostana. Planta Medica, 62 (4), 381-382. https://doi.org/10.1055/s-2006-957916

Ciochina, R., \& Grossman, R. B., (2006). Polycyclic polyprenylated acylphloroglucinols. Chemical Reviews, 106 (9), 3963-3986. https://doi.org/10.1021/cr0500582

Costa Júnior, J. S., Feitosa, C. M., Citó, A. M. G. L., Freitas, R. M., Henriques, J. A. P., \& Saffi, J. (2010). Evaluation of Effects of Ethanolic Extract from Platonia insignis Mart. on Pilocarpine-induced Seizures. Journal of Biological Sciences, 10 (8), 747-753. https://doi.org/10.3923/jbs.2010.747.753

Costa Júnior, J. S., Ferraz, A. B. F., Filho, B. A. B., Feitosa, C. M., Citó, A.M.G.L., Freitas, R. M., \& Saffi, J. (2011a). Evaluation of antioxidant effects in vitro of garcinielliptone FC (GFC) isolated from Platonia insignis Mart. Journal of Medicinal Plants Research, 5 (2), $293-299$.

Costa Júnior, J. S., Almeida, A. A. C., Tomé, A. R., Citó, A. M. G. L., Saffi, J., \& Freitas, R. M. (2011b). Evaluation of possible antioxidant and anticonvulsant effects of the ethyl acetate fraction from Platonia insignis Mart. (Bacuri) on epilepsy models. Epilepsy \& Behavior, 22 (4), 678-684. https://doi.org/10.1016/j.yebeh.2011.09.021

Costa Júnior, J. S., de Almeida, A. A. C., Costa, J. P., Citó, A. M. D. L., Saffi, J., \& de Freitas, R. M. (2012). Superoxide dismutase and catalase activities in rat hippocampus pretreated with garcinielliptone FC from Platonia insignis. Pharmaceutical Biology. 50 (4), 453-457. 10.3109/13880209.2011.611146 
Cuesta-Rubio, O., Piccinelli, A. L., \& Rastrelli, L. (2005). Chemistry and biological activity of polyisoprenylated benzophenone derivatives. Studies in Natural Products Chemistry, 32, 671-720. https://doi.org/10.1016/S1572-5995(05)80066-3

Denizot, F., \& Lang, R. (1986). Rapid colorimetric assay for cell growth and survival. Modifications to the tetrazolium dye procedure giving improved sensitivity and reliability. Journal of Immunological Methods, 89 (2), 271-277. https://doi.org/10.1016/0022-1759(86)90368-6

Devi, G., Sudhakar, K., Vasupradaa, A. P., Sravya, V., Manasa, V., \& Yasaswini, E. (2021). Medicinal Plants in India and it's Antioxidant Potential-A Review. Revista geintec-gestao inovacao e tecnologias, 11 (4), 1397- 1405. https://doi.org/10.47059/revistageintec.v11i4.2195

Doroftei, E., Miron, L., \& Beleniuc, G. (2019). Evaluation of cytogenetic and genotoxic potential of crude aqueous extract of Plantago lanceolata. International Multidisciplinary Scientific GeoConference: SGEM, 19 (6.1), 697-704. https://doi.org/10.5593/sgem2019/6.1/S25.090

Garg, A. K., Faheem, M., \& Singh, S. (2021). Role of Medicinal Plant in Human Health Disease. Asian Journal of Plant Sciences, 11, 19-21. https://doi.org/10.24941/ijcr.40170.11.2020

Hartmann, A., Elhajouji, A., Kiskinis, E., Poetter, F., Martus, H., Fjallman, A., Frieauff, W., \& Suter, W. (2001). Use of the alkaline comet assay for industrial genotoxicity screening: comparative investigation with the micronucleus test. Food and Chemical Toxicology, 39 (8), 843-858. https://doi.org/10.1016/s02786915(01)00031-x

Hartmann, A., \& Speit, G. (1997). The contribution of cytotoxicity to DNA-effects in the single cell gel test (comet assay). Toxicology Letters, 90 (2-3), 183188. https://doi.org/10.1016/s0378-4274(96)03847-7

Hartman, L., \& Lago, R. C. (1973). Rapid preparation of fatty acid methyl esters from lipids. Laboratory Practice, 22 (6), 475-476.

Hilditch, T. P., \& Pathak, S. P. (1949). S 17 The component glycerides of Bacury (Platonia insignis Mart.) seed fat. Journal of the Chemical Society, S87-S90.

Hosni, K., Msaâda, K., Taârit, M. B., Hammami, M., \& Marzouk, B. (2010). Bioactive components of three Hypericum species from Tunisia: A comparative study. Industrial Crops and Products, 31 (1), 158-163. https://doi.org/10.1016/j.indcrop.2009.09.018

Iinuma, M., Tosa, H., Tanaka, T., Asai, F., Kobayashi, Y., Kobayashi, R., \& Miyauchi, K. (1996). Antibacterial activity of xanthones from guttiferaeous plants against methicillin-resistant Staphylococcus aureus. Journal of Pharmacy and Pharmacology, 48 (8), 861-865. https://doi.org/10.1111/j.20427158.1996.tb03988.x

Laphookhieo, S., Syers, J. K., Kiattansakul, R., \& Chantrapromma, K. (2006). Cytotoxic and antimalarial prenylated xanthones from Cratoxylum cochinchinense. Chemical \& pharmaceutical bulletin, 54 (5), 745-747. https://doi.org/10.1248/cpb.54.745

Marti, G., Eparvier, V., Moretti, C., Susplugas, S., Prado, S., Grellier, P., Retailleau, P., Gueritte, F., \& Litaudon, M. (2009). Antiplasmodial benzophenones from the trunk latex of Moronobea coccinea (Clusiaceae). Phytochemistry, 70 (1), 75-85. https://doi.org/10.1016/j.phytochem.2008.10.005

Matos, F. J. A., Lorenzi, H., Santos, L. F. L., Matos, M. E. O., Silva, M. G. V. \& Sousa, M. P, (2011). Plantas tóxicas: estudo de fitotoxicologia química de plantas brasileiras. Nova Odessa: Plantarum, 256p.

Matsumoto, K., Akao, Y., Ohguchi, K., Ito, T., Tanaka, T., Iinuma, M., \& Nozawa, Y. (2005). Xanthones induce cell-cycle arrest and apoptosis inhuman colon cancer DLD-1 cells. Bioorganic \& Medicinal Chemistry, 13 (21), 6064-6069. https://doi.org/10.1016/j.bmc.2005.06.065

McLaughlin, J. L., McLaughlin, J., \& MacLaughlin, J. L. (1991). Crown gall tumours on potato discs and brine shrimp lethality: two simple bioassays for higher plant screening and fractionation. Methods in Plant Biochemistry, 6, 1-32.

Mesquita, M. L., Paula, J. E., Pessoa, C., Moraes, M. O., Costa-Lotufo, L.V., Grougnet, R., Michel, S., Tillequin, F., \& Espindola, L. S. (2009). Cytotoxic activity of Brazilian Cerrado plants used in traditional medicine against cancer cell lines. Journal of Ethnopharmacology, 123 (3), 439-445. https://doi.org/10.1016/j.jep.2009.03.01

Meyer, B.N., Ferrigni, N. R., Putnam, J. E., Jacobsen, L. B., Nichols, D. E., \& McLaughlin, J. L. (1982). Brine shrimp: a convenient general bioassay for active plant constituents. Plantamed, 45 (5), 31-34. https://doi.org/10.1055/s-2007-971236

Møller, P., Möller, L., Godschalk, R. W. L., \& Jones, G. D. D. (2010). Assessment and reduction of comet assay variation in relation to DNA damage: studies from the European Comet Assay Validation Group. Mutagenesis, 25 (2), 109-111. https://doi.org/10.1093/mutage/gep067

Monteiro, A. R., Meireles, M. A. A., Marques, M. O. M., \& Petenate, A. J. (1997). Extraction of the soluble material from the shells of the bacuri fruit (Platonia insignis Mart) with pressurized $\mathrm{CO}_{2}$ and other solvents. Journal of Supercritical Fluids, 11 (1-2), 91-102. https://doi.org/10.1016/S08968446(97)00028-4

Nadin, S. B., Vargas-Roig, L. M., \& Ciocca, D. R. (2001). A silver staining method for single-cell gel assay. Journal of Histochemistry and Cytochemistry, 49 (9), 1183-1186. https://doi.org/10.1177/002215540104900912

Oliveira-Silva, F., Morais-Teixeira, E., \& Rabello, A. (2008). Antileishmanial Activity of Azitahromycin Against Leishmania (Leishmania) amazonensis, Leishmania (Viannia) braziliensis, and Leishmania (Leishmania) chagasi. American Journal of Tropical Medicine and Hygiene, 78 (5), 745-749. https://doi.org/10.4269/ajtmh.2008.78.745

Pereira, I. O., Marques, M. J., Pavan, A. L. R., Codonho, B. S., Barbiéri, C. L., Beijo, L.A., Doriguetto, A.C., D'Martin, E. C., \& Dos Santos, M. H. (2010). Leishmanicidal activity of benzophenones and extracts from Garcinia brasiliensis Mart. fruits. Phytomedicine, 17 (5), $339-345$. https://doi.org/10.1016/j.phymed.2009.07.020

Pedraza-Chaverri, J., Cardenas-Rodriguez, N., Orozco-Ibarra, M., \& Perez-Rojas, J. M. (2008). Medicinal properties of mangosteen (Garcinia mangostana). Food and Chemical Toxicology, 46 (10), 3227-3239. https://doi.org/10.1016/j.fct.2008.07.024 
Piccinelli, A. L., Cuesta-Rubio, O., Chica, M. B., Mahmood, N., Pagano, B., Pavone, M., Barone, V., \& Rastrelli, L. (2005). Structural revision of clusianone and 7-epi-clusianone and anti-HIV activity of polyisoprenylated benzophenones. Tetrahedron, 61 (34), 8206-8211. https://doi.org/10.1016/j.tet.2005.06.030

Prado, L. S., da Silva, J., Garcia, A. L. H., Boaretto, F. B. M., Grivicich, I., Conter, L.U., Salvi, A. O., Reginatto, F. H., Vencato, S. B., Ferraz, A. B. F., \& Picada, J. N. (2017). Evaluation of DNA Damage in HepG2 Cells and Mutagenicity of Garcinielliptone FC, A Bioactive Benzophenone. Basic \& Clinical Pharmacology \& Toxicology, 120 (6), 621-627. https://doi.org/10.1111/bcpt.12753

Ricchi, M., Odoardi, M. R., Carulli, L., Anzivino, C., Ballestri, S., Pinetti, A., Fantoni, L. I., Marra, F., Bertolotti, M., Banni, S., Lonardo, A., Carulli, \& N., Loria, P. (2009). Differential effect of oleic and palmitic acid on lipid accumulation and apoptosis in cultured hepatocytes. Journal of Gastroenterology and Hepatology, 24 (5), 830-840. https://doi.org/10.1111/j.1440-1746.2008.05733.x

Schultz, F., Osuji, O. F., Nguyen, A., Anywar, G., Scheel, J. R., Caljon, G., Pieters, L., \& Garbe, L. A. (2021). Pharmacological Assessment of the Antiprotozoal Activity, Cytotoxicity and Genotoxicity of Medicinal Plants Used in the Treatment of Malaria in the Greater Mpigi Region in Uganda. Frontiers in Pharmacology, 12, 1-26. https://doi.org/10.3389/fphar.2021.678535

Silva, A. P. D. C. L., Oliveira, G. L. D., Medeiros, S. C., Sousa, A. M. L., Lopes, L. D., David, J. M., da Costa Júnior, J. S., \& de Freitas, R. M. (2016). Preclinical toxicology of garcinielliptone FC, a tautomeric pair of polyprenylated benzophenone, isolated from Platonia insignis Mart seeds. Phytomedicine, 23 (5), 477-482. https://doi.org/10.1016/j.phymed.2016.02.013

Silva, A. P. S. C. L., Lopes, J. S. L., Vieira, P. S., Pinheiro, E. E. A., da Silva, M. L. G., Silva-Filho, J. C. C. L., Costa Júnior, J. S., David, J. M., \& de Freitas, R.M. (2014). Behavioral and neurochemical studies in mice pretreated with garcinielliptone FC in pilocarpine induced seizures. Pharmacology Biochemistry and Behavior, 124, 305-310. https://doi.org/10.1016/j.pbb.2014.05.021

Silva, A. P., Silva, M. P., Oliveira, C. G., Monteiro, D. C., Pinto, P. L., Mendonca, R. Z., Costa Júnior, J. S., Freitas, R. M., \& de Moraes, J. (2015). Garcinielliptone FC: Antiparasitic activity without cytotoxicity to mammalian cells. Toxicology in Vitro, 29 (4), 681-687. https://doi.org/10.1016/j.tiv.2014.12.014

Souza, V. A. B., Vasconcelos, L. F. L., Araújo, E. C. E., \& Alves, R. E. (2000). Bacurizeiro: Platonia insignis Mart., São Paulo: Jaboticabal.

Souza, A. C., Alves, M. M. M., Brito, L. M., Oliveira, L. G. C., Sobrinho-Júnior, E. P. C., Costa, I. C. G., Freitas, S. D. L., Rodrigues, K. A. D. F., Chaves, M. H., Arcanjo, D. D. R., \& Carvalho, F. A. A. (2017). Platonia insignis Mart., a Brazilian Amazonian Plant: The Stem Barks Extract and Its Main Constituent Lupeol Exert Antileishmanial Effects Involving Macrophages Activation. Evidence-based Complementary and Alternative Medicine, 2017:3126458. https://doi.org/10.1155/2017/3126458

Suksamrarn, S., Suwannapoch, N., Phakhodee, W., Thanuhiranlert, J., Ratananukul, P., Chimnoi, N., \& Suksamrarn, A. (2003). Antimycobacterial activity of prenylated xanthones from the fruits of Garcinia mangostana. Chemical and Pharmaceutical Bulletin, 51 (7), 857-859. https://doi.org/10.1248/cpb.51.857

Suksamrarn, S., Komutiban, O., Ratananukul, P., Chimnoi, N., Lartpornmatulee, N., \& Suksamrarn, A. (2006). Cytotoxic prenylated xanthones from the young fruit of Garcinia mangostana. Chemical and Pharmaceutical Bulletin, 54 (3), 301-305. https://doi.org/10.1248/cpb.54.301

Tice, R. R., Agurell, E., Anderson, D., Burlinson, B., Hartmann, A., Kobayashi, H., Miyamae, Y., Rojas, E., Ryu, J. C., \& Sasaki, Y. F. (2000). Single cell gel/comet assay: guidelines for in vitro and in vivo genetic toxicology testing. Environmental and Molecular Mutagenesis, 35 (3), 206-221. https://doi.org/10.1002/(sici)1098-2280(2000)35:3<206::aid-em8>3.0.co;2-j

The Plant List (2022). Published on the Internet: <http://www.theplantlist.org/1.1/browse/A/Clusiaceae/>

Tropicos. (2022). Base de dados do Missouri Botanical Garden. <http://www.tropicos.org>.

Varanda, E. A., Pozetti, G. L., Lourenço, M. V., Vilegas, W., \& Raddi, M. S. G. (2002). Genotoxicity of Brosimum gaudichaudii measured by the Salmonella/microsome assay and chromosomal aberrations in CHO cells. Journal of Ethnopharmacology, 81 (2), 257-264. https://doi.org/10.1016/s03788741(02)00089-2

Wang, J. J., Sanderson, B. J. S., \& Zhang, W. (2011). Cytotoxic effect of xanthones from pericarp of the tropical fruit mangosteen (Garcinia mangostana Linn.) on human melanoma cells. Food and Chemical Toxicology, 49 (9), 2385-2391. https://doi.org/10.1016/j.fct.2011.06.051

Weng, J. R., Tsao, L. T., Wang, J. P., Wu, R. R., \& Lin, C. N. (2004). Anti-inflammatory phloroglucinols and terpenoids from Garcinia subelliptica. Journal of Natural Products, 67 (11), 1796-1799. https://doi.org/10.1021/np049811x

Zhang, L. J., Chiou, C. T., Cheng, J. J., Huang, H. C., Kuo, L. M. Y., Liao, C. C., Bastow, K. F., Lee, K. H., \& Kuo, Y. H. (2010). Cytotoxic polyisoprenyl benzophenonoids from Garcinia subelliptica. Journal of Natural Products, 73 (4), 557-562. https://doi.org/10.1021/np900620y 